\title{
The Relationship between Communication Competence and Organizational Conflict: \\ A Study on Head of Educational Supervisors
}

\section{Mehmet ÜSTÜNER ${ }^{*}$}

Ali KIŞ**

\section{Suggested Citation:}

Üstüner, M., Kış, A. (2014). The Relationship between communication competence and organizational conflict: a study on head of educational supervisors. Eurasion Journal of Educational Research, 56, 1-24, DOI: http:/ /dx.doi.org/10.14689/ejer.2014.56.5

\begin{abstract}
Problem Statement: Since conflict is an organizational phenomenon, its comparison between other organizational variables to find possible associations has been an important research motive. Relevant researchers have found significant correlations between conflict handling strategies of principals of different genders and school culture, emotional intelligence and conflict management styles, teachers' self-efficacy beliefs and conflict solution styles. Considering the rapid development of communication and the need for organizations to change, an increase in individual differences between organization members has become inevitable today. This also causes increased conflicts between organization members who are constantly interacting with each other. Poor communication underlies the interpersonal conflicts. The degree of interpersonal communication significantly determines the organizational performance and information transmission. Each education organization, like other organizations, is composed of people with different personalities, perceptions, attitudes, value judgments, personal goals, and expectations. Individual differences cause some problems. Solution of the problems seems to be closely associated with communication competence organization members have.
\end{abstract}

Purpose of Study: This study investigates the relationship between communication competences and organizational conflict levels of heads of

\footnotetext{
* Corresponding Author: Assoc. Prof. Dr., Inonu University, Education Faculty, Department of Educational Sciences, 44280 Battalgazi-Malatya, TURKEY mehmet.ustuner@inonu.edu.tr

${ }^{*}$ Assist. Prof. Dr. Inonu University, Education Faculty, Department of Educational Sciences, 44280 Battalgazi-Malatya, TURKEY ali.kis@inonu.edu.tr
} 
educational supervisors, and the extent to which communication competence predicts organizational conflict.

Methods: This associational study was conducted on 217 educational supervisors working in head departments of educational supervisors in eight cities of Turkey. Data were collected using "Communication Competences Scale" and "Organizational Conflict Scale".

Findings and Results: Results indicated that heads of educational supervisors mostly exhibit communication competences including the components of empathy, social relaxation and support behaviors. Educational supervisors also stated that they sometimes experience organizational conflict including the components of intergroup, between groups and personal conflict in their head departments. A negative moderate level of correlation was found between communication competence and organizational conflict levels of heads of educational supervisors. And communication competence was found to predict organizational conflict significantly. Additionally, it was found that empathy competence, one of the communication competences, is a significant predictor of intergroup and personal conflict, and support competence is a significant predictor of within group conflict. Also it was found that social relaxation competence as one of the components of communication competence is not a significant predictor of any of the components of organizational conflict.

Conclusions and Recommendations: This study provides new insight into the effects of communication competence on conflict management in educational organizations and is of value to educational leaders, managers, and other conflict management specialists.

Keywords: Educational supervisors, Communication competence, Organizational conflict,

\section{Introduction}

One way of authenticating the quality of the teachers and school programs is through evaluation process. Thus, supervision's first priority is to oversee the efficiency and effectiveness of school community. This process can sometimes be threatening, depersonalizing, humiliating since it places individuals superior versus inferior roles. When it comes to supervisory team, for the head of the team and other members of the team, positional authority seems to be more important than an authority based on competence.

Bursalığlu (1994, p. 129) defines inspection (evaluation) as a method of controlling behavior for public good. He also sees inspection as one of the most frequently used regulatory mechanisms to ensure cohesiveness in education system. Inspection can also be defined as the process of monitoring whether organizational 
acts are in line with the goals, principles and rules agreed. The main goal of inspection is to detect to what extent the organizational goals have been achieved, to take precautions for better outcomes and to improve the process (Aydin, 2000, p. 11).

One important unit of Turkish Education System, the Head Department of Educational Supervisors has important roles in executing the inspectional duties as a part of schools' administration process (Article I, Law No 5984, published in Official Gazette dated 13.06.2010 and numbered 27610). The duties of the educational supervisors were specified in Law No 5984 as follows:

Educational supervisors' and deputy inspectors' fields of assignment include the services of guiding, in-service training, supervision, inspection, assessment, examination, research and investigation of organized and extensive education institutions of all types and levels, except for the guidance and inspection of directorates of national education in provinces and districts and the secondary education institutions, and the analysis and investigation of teachers working in these institutions regarding their subject fields.

As legally specified the heads of educational supervisors are assigned to inspect, assess, examine, and investigate the institutions and to guide and train the staff on service.

Highlighting different role classifications of educational inspectors based on variables in role construction, Başar (2000, p. 39) distinguishes the supervisors roles as leadership, administration, guidance, help, training, research and investigation under three scopes: duty, process and behavior. Like other professionals educational supervisors are expected to have some competencies to perform their roles.

Competency: To Phillips (1983) defining competency is like climbing an oily post and when you think you have done, it goes out of your hand. Phillips (1983) defines competence as anything required by the job definition or communication goal however it is measured under certain circumstances. Competence is one's belief in accomplishing a job and is a must to motivate that person. Competence can be observed through behaviors and classified according to situational positions.

Spitzberg (1983) compares his views on competence with those of McCroskey. Spitzberg states that McCroskey distinguishes competence from skill, performance and productivity and it is held in three traditional behavioral domains: psychomotor, affective and cognitive. Spitzberg reports that McCroskey takes competence for knowledge. To Spitzberg (1983) distinction between motivation, knowledge and competence is important. For "performance" can be enhanced or restricted by any or all of these. The independence of motivation, knowledge and competence has been highlighted in many researches. Competence is not naturally inherent in one's behaviors but a produced result of an event. In other words, one's competence should be handled in a certain context.

The term competence has different definitions which can be categorized as theoretical and operational. Theoretical ones defines competence as the existence or 
absence of qualifications to perform a role considering it a potential, whereas operational definitions refer to competence as the ability to perform a task at a certain place and a required time as the vivid indicator of that potential (Başar, 2000, p. 97-98).

Başar (2000) groups supervisor competences with regard to some fields including course inspection, institution inspection, research and investigation. Taymaz (1982, p. 4) stressed that inspectors' fields of competences can be categorized under six including administration, leadership, guidance, teaching, research expertise, and investigation. One competence commonly required for all of these competences classified above seems to be communication competence.

Communication competence: To Rickheit, Strohner and Vorwerg (2008, p.18) the term communication competence was used by Dell Hymes in 1969 to stress knowledge of grammar rules rather than spoken communication competence. They cite that Wiemann (1977), Spitzberg ve Cupach $(1984,1989)$ contributed significantly to the expansion of the scope of communication competence. In Wiemann's (1977) study it was emphasized that communication competence approaches can be handled under three groups, t-group, social skill, and self-expression. Wiemann (1977, p. 198) defines communication competence "the ability of an interactant to choose among available communicative behaviors in order that he (she) may successfully accomplish his (her) own interpersonal goals during an encounter while maintaining the face and line of his (her) fellow interactants within the constraints of the situation", states that communication competence is a combination of five basic skills including affiliation/support, social relaxation, empathy, behavioral flexibility and interaction management. Rubin and Martin (1994) handles interpersonal communication competence under such categories as self-disclosure, empathy, social relaxation, assertiveness, interaction management, altercentrism, expressiveness, supportiveness, immediacy and environmental control. Hoy and Miskel (2010, p. 347) consider communication competence as a set of skills and researches one interactant possess. In this regard people with communication competence are expected to be able to send messages, listen to and feedback well.

Blatt and Benz (1993) also found that support and empathy competences are related with students' respect to teacher, and other-focusedness is strongly associated with the items in students' teacher evaluation scale. In addition to this, competences in social relaxation, interaction management, self-disclosure, assertiveness dimensions were found to be slightly associated with the items in students' teacher evaluation scale. It was also emphasized that empathy and supportiveness were basic components of communication competence.

Myers and Kassing (1998) reported that seniors' communication competences are significant predictor of juniors' organization perception, and juniors with high level of organizational identity perception judge their seniors as more competent in communication and more participative in interaction than the juniors with moderate and low levels of organizational identity perception. It was also reported that principals' communication competences are strongly correlated with effective 
leadership skills (Sophie, 2004). Johns (1997) found that effective educational leadership is highly correlated with competences regarding starting communication, listening, sending and waiting for feedback, and public affairs. Şimşek (2003) reported a strong positive correlation between principals' communication competences and sound culture of schools (Şimşek, 2003). Contrary to these findings, no correlation between inspectors' communication competences and effective inspection was also reported (Craig, 2000).

Smith (2004), comparing the communication strategies of principals in high and low SES schools, found that principals working in schools in low SES milieu generally use their communication strategies to manipulate the school staff, whereas those in schools in upper SES milieu use their communication strategies for problem solving, critical thinking, enhancing and introducing the student personality and performance. No significant association was found between primary school principals' interpersonal communication competence, organizational conflict and school climate, but a significant correlation was found between primary school principals' interpersonal communication competence and interpersonal conflict (Tabor, 2001). A research on technical and office staff working in the field of communication technologies revealed that workers with high performance are more motivated compared to low performing workers to adapt to communication and have more empathic communication competence (Payne, 2005).

Organizational conflict: Organizational conflict is defined in different ways. Conflict is mainly caused by parties' perception of conflict, opposition, contrast, prevention and presence of two or more groups with seemingly non-compatible goals and interests (Aydın, 2000, p. 292). Conflict is an attempt of one party to neutralize the efforts of other (Robbins, 1994, p. 220). Organizational conflict is the state of interaction between workers and clusters with irreconcilable differences or non-compatible characters. The conflict behavior of interacting people is a reaction to events and contradictions affecting their cognitive and affective strengths (Başaran, 2004, p. 323). However the conflict is defined, it is composed of certain elements such as disagreement, opposition and disharmony. Conflict is an inevitable phenomenon in the social life where people interact (Bursalığlu, 2002; Karip, 2003; Şimşek, Akgemci, Çelik, 2001). An organization without any conflict is dead. In living and functioning organizations presence of conflict is inevitable and natural (Açikalın, 1998, p. 107).

Types of Organizational Conflict: To Rahim (2000, p. 20) types of conflicts can be classified according to sources of conflict and the organizational levels they arise. Types of conflicts according to sources of conflict are emotional conflict, task conflict, conflict of interest, value conflict, goal conflict, realistic and unrealistic conflict, institutionalized and non-institutionalized conflict, punitive conflict, causeless conflict and misattributed conflict, and displaced conflict. Conflicts classified according to organizational levels they arise are intrapersonal, interpersonal, intragroup, and intergroup conflicts (Rahim, 2001, p.33). 
Intrapersonal conflict: It is tension experienced within the individual due to actual or perceived pressures from incompatible goals or expectations (Schermerhorn, Hunt, Osborb and Uhl-Bien, 2010, 233). Intrapersonal conflicts emerge when organization members are asked to perform tasks incompatible with their expertise, experience, interests, goals and values (Rahim, 2001, p.23). It is the kind of conflict people experience when they face two controversial situations either negative or positive and cannot decide between the two (Kirel, 1996, p. 212). For someone to undertake conflicting and opposing roles and to be obliged to choose between these roles, it causes intrapersonal conflict, or of roles (Karip, 2003, p.24).

Interpersonal conflicts: They are the conflicts between hierarchical levels, units or organization members with similar ranks (Rahim, 2001, p.23). They are the kind of conflicts between two or more people. It emerges when there are differences between goals, attitudes, values and behaviors (Kirel, 1996, p. 212, Başaran 2004, p. 327). Interpersonal conflict occurs between two or more individuals who are in opposition to one another. It may be substantive, emotional, or both. Interpersonal conflict often arises in the performance evaluation process (Schermerhorn, Hunt, Osborb and UhlBien, 2010, p. 233). The conflicts caused by personal incompatibility or disagreement between command-staff managers with senior-junior conflicts can be said to be common types of interpersonal conflicts in organizations. Also lack of harmony between workers, differences in the views, ideas and interests between managerschiefs-officers can be examples of interpersonal conflicts (Eren, 2000, p.535).

Intragroup conflicts: These kind of conflicts occur when group members or subgroup members experience conflict initiating situations such as disagreements in goals, tasks or procedures. Moreover, intragroup conflicts can emerge as a result of disagreements and tensions between group members and group leader (Rahim, 2001, p. 23-24).

Intergroup conflict: it occurs between teams, perhaps ones competing for scarce resources or rewards, and perhaps ones whose members have emotional problems with one another. Intergroup conflict is quite common in organizations, and it can make the coordination and integration of task activities very difficult (Schermerhorn, Hunt, Osborb \& Uhl-Bien, 2010, 233). They are also known as interdepartmental conflict. They resemble the conflicts between departments or groups in an organization (Rahim, 2001, p. 24). Conflicts between elementary teachers and subject teachers are examples of intergroup conflicts (Karip, 2003, p. 25). Intergroup conflicts can be distinguished as vertical conflict, horizontal conflict, staff-manager conflict and conflicts based on differences (Hellriegel, Slocum \& Woodman, 1995, p. 439).

Since conflict is an organizational phenomenon, its comparison between other organizational variables to find possible associations has been an important research motive (Gümüşeli, 1994; Özmen, 1997; Polat, 2004; Türnüklü, 2002; Yıldırım, 2003). Relevant researchers have found significant correlations between conflict handling strategies of principals of different genders and school culture (Blackburn, 2002), emotional intelligence and conflict management styles (Atay, 2002; Lee, 2003), teachers' self-efficacy beliefs and conflict solution styles (Roberts, 1997). 
Considering the rapid development of communication and the need for organizations to change, an increase in individual differences between organization members has become inevitable today. This also causes increased conflicts between organization members who are constantly interacting with each other (Karip, 2003, 1). Poor communication underlies the interpersonal conflicts. The degree of interpersonal communication significantly determines the organizational performance and information transmission (Robbins, 1994, p. 141). As cited in Payne (2005) communication competence and skills in an organization is associated with such organizational outputs as vertical mobility, administrational performance, leadership skills, worker commitment, job performance, and senior acceptance. Each education organization, like other organizations, is composed of people with different personalities, perceptions, attitudes, value judgments, personal goals, and expectations. Individual differences cause some problems. Solution of the problems seems to be closely associated with communication competence organization members have.

In Turkish education system, supervisory tasks are carried out through counselling and supervisory department of national ministry. This department has head of educational supervisory that consists of head supervisors, supervisors and vice-supervisors. According to the ministry regulations, the heads are chosen and assigned among supervisors. Also there are lots of tasks a head faces in daily routine, that necessitate communication competencies. When administration, organization and supervision tasks taken into account, it is mandatory that a head should have healthy communication skills. Communication competence is also used by the head in mentoring and guiding the supervisors to prepare for the profession. Presidising in meetings, organizing and coordinating commissions and delegating tasks are all daily routine tasks a head encounters often, which all demand competency in communication. So far, there has been no research for this group in the literature. This research is the first one to supply invaluable data for the heads of educational supervisors.

The purpose of this study was to examine the relationship between organizational conflict level and communication competence of the heads of educational supervisors according to the views of educational supervisors working under head supervisors. Accordingly, following questions were answered in this study:

1. What is the communication competence (empathy", "social relaxation" and "support") level of heads of educational supervisors according to the views of educational supervisors?

2. What is the level of organizational conflict ("intragroup conflict", "intergroup conflict" and "personal conflict") in the department where educational supervisors work?

3. Does the communication competence level of heads of educational supervisors' significantly predict level of organizational conflict? 
4. Do the components of communication competence (empathy, social relaxation and support) among heads of educational supervisors significantly predict intragroup conflict, intergroup conflict, and personal and total conflict level in their organization?

The study facilitates understanding of how to unbundle the linkage between communication competence and conflict management in educational supervisory departments, along with making contributions to conflict theory. It also provides new insight into the effects of communication competence on conflict management in educational organizations and is of value to organizational leaders, managers, and other conflict management specialists.

\section{Method}

This is a relational descriptive survey, conducted on educational supervisors working in head departments of educational supervisors in eight cities of Turkey. In correlational research, researchers attempt to determine whether a relationship exists between two (or more) quantitative variables (Fraenkel, Wallen and Hyun, 2012). Linear regression analysis and comparisons of correlations were utilized to examine relationships between communication competence and conflict management.

\section{Research group}

One of the non-random sampling methods, purposive sampling was chosen since on occasion, based on previous knowledge of a population and the specific purpose of the research, researchers use their personal judgement when they need to select a sample (Fraenkel et al., 2012).

A total of 446 educational supervisors working in head departments of educational supervisors in Turkish cities, Adıyaman, Diyarbakır, Hatay, Kayseri, Malatya, Kahramanmaraş, Tokat and Şanlıurfa Provincial Directorates of National Education were sent the instrument during 2010-2011 school year. But only 217 educational supervisors (14 women and 203 men) responded to the instrument, which were evaluated in this study. Among these participating educational supervisors 171 had undergraduate and 46 had postgraduate degrees. The distribution of participating educational supervisors according to provinces and response rates are presented in Table 1. 
Table 1

Distribution of Participating Educational Supervisors According to Provinces and Response Rates

\begin{tabular}{lccc}
\hline Cities & $\begin{array}{c}\text { Total number of } \\
\text { Educational } \\
\text { supervisors }\end{array}$ & $\begin{array}{c}\text { Number of participating } \\
\text { Educational supervisors }\end{array}$ & $\begin{array}{c}\text { Response } \\
\text { rate }\end{array}$ \\
\hline Adiyaman & 43 & 28 & $65 \%$ \\
Diyarbakır & 48 & 22 & $46 \%$ \\
Hatay & 57 & 37 & $65 \%$ \\
Kayseri & 58 & 22 & $38 \%$ \\
Malatya & 55 & 33 & $60 \%$ \\
Kahramanmaraş & 60 & 27 & $45 \%$ \\
Tokat & 35 & 24 & $69 \%$ \\
Şanliurfa & 90 & 24 & $27 \%$ \\
Total & $\mathbf{4 4 6}$ & $\mathbf{2 1 7}$ & $\mathbf{4 9} \%$ \\
\hline
\end{tabular}

\section{Research Instruments and Procedures}

In order to collect data about communication competence levels of heads of educational supervisor and levels of organizational conflict based on educational supervisors' views, I used the Turkish adaptations (Topluer, 2008) of "Communication Competence Scale-CCS" originally developed by Wiemann (1977) and "Rahim Organizational Conflict Inventory; ROCI-I" originally developed by Rahim (1983).

Communication Competence Scale-CCS: The 5-point (Always-Never) Likert type scale with 36 items was adapted into Turkish by Topluer (2008) using data obtained from 255 teachers working in Malatya, Elazığ and Adiyaman city centers. The exploratory factor analysis revealed a three-factor structure where items 6, 30, 8, 10 and 20 were discarded due to low factor loadings. The factors were named "empathy" (17 items), "social relaxation" (7 items) and "support" ( 7 items). Items 4 , $8 ., 9$ and 24 in support factor need to be reverse coded. The internal consistency coefficients (Cronbach's alpha) estimated for each factor of CCS and for the overall scale were high ( $\alpha=.96$ for empathy, $\alpha=.87$ for social relaxation, $\alpha=.86$ for support factor, and $\alpha=.96$ for overall scale (Topluer, 2008). For the present study the internal consistency coefficients were estimated $\alpha=.97$ for empathy, $\alpha=.90$ for social relaxation, $\alpha=.74$ for support factor, and $\alpha=.97$ for overall CCS. In interpretation of the scale points, minimum and maximum points are taken into account. For instance, from 17-items empathy factor can produce minimum 17 points and maximum 85 points $(17 \times 5)$. To interpret this range the following intervals are used: 0-17 never, 1834 rarely, 35-51 sometimes, 52-68 generally and 69-85 always.

Rahim Organizational conflict inventory (ROCI-I): ROCI-I developed by Rahim (1983) is composed of 24 items under three factors (personal conflict, intragroup conflict and intergroup conflict). It is a five-point Likert type instrument.

To test the construct validity of ROCI-I, factor analysis was done using data obtained from 255 teachers. As a result of the analysis $22^{\text {nd }}$ item was discarded because of low factor loading. Resulting scale contained 9 items in intragroup 
conflict factor, 8 items in intergroup conflict factor, and 6 items in intrapersonal conflict factor. The items 2, 3, 7, 9, 14, 15 and 20 intergroup conflict factor and items 4, $8,12,16$, and 22 (original item no 23) in intrapersonal conflict factor are reversed items. The increase in the scores from ROCI-I in general and factors indicates increased organizational conflict. The internal consistency coefficients (Cronbach's alpha) were found .85 for intrapersonal conflict factor, .85 for intragroup conflict, and .55 for intergroup conflict. The internal consistency coefficient was estimated .81 for the entire inventory (Topluer, 2008). For the present study the internal consistency coefficients were estimated $\alpha=.78$ forpersonal conflict, $\alpha=.86$ for intragroup conflict, $\alpha=.70$ for intergroup conflict, and $\alpha=.84$ for overall ROCI-I.

\section{Data analysis}

The data were analyzed using descriptive techniques and linear regression analysis. To this end multiple and simple linear regression analysis were used to test if scores from overall communication competence scale and its factors (independentpredicting variable) significantly predict the scores from overall organizational conflict scale and its factors (dependent-predicted variable) (Çokluk, Şekercioğlu ve Büyüköztürk, 2010).

\section{Results}

The findings about the communication competence (empathy", "social relaxation" and "support") levels of heads of educational supervisors according to the views of educational supervisors are presented in Table 2.

Table 2

Heads of Educational Supervisors' Level of Communication Competence

\begin{tabular}{llllll}
$\begin{array}{l}\text { Communication } \\
\text { competence }\end{array}$ & $\boldsymbol{N}$ & $\overline{\mathrm{X}}$ & $\boldsymbol{S d}$ & Minimum & Maximum \\
\hline Empathy & 217 & 68,12 & 13,49 & 22,00 & 85,00 \\
Social relaxation & 217 & 26,80 & 5,78 & 7,00 & 35,00 \\
Support & 217 & 27,88 & 4,68 & 13,00 & 35,00 \\
Total & $\mathbf{2 1 7}$ & $\mathbf{1 2 2 , 8 1}$ & $\mathbf{2 2 , 4 6}$ & $\mathbf{5 0 , 0 0}$ & $\mathbf{1 5 5 , 0 0}$ \\
\hline
\end{tabular}

The analysis revealed that, according to the views of educational supervisors, the empathy competence mean score of the heads of educational supervisors was $\bar{X}=$ 68.12 , the social relaxation score was $\bar{X}=26.80$, and the support competence mean 
score was $\bar{X}=27.88$. This finding suggests that based on educational supervisors' views, the heads of educational supervisors "generally" display the behaviors regarding empathy, social relaxation and support competences as the components communication competence. The overall score for the communication competence of heads of educational supervisors according to the educational supervisors was $\bar{X}=122.81$, which also indicate that the heads of educational supervisors "generally" display the behaviors requiring communication competence.

The findings about the level of organizational conflict ("intragroup conflict", "intergroup conflict" and "personal conflict") in the departments where educational supervisors work are presented in Table 3.

Table 3

The Level of Organizational Conflict in Head Departments of Educational Supervisors

\begin{tabular}{llllll}
\hline $\begin{array}{l}\text { Organizational } \\
\text { conflict }\end{array}$ & $N$ & $\bar{X}$ & $S \boldsymbol{d}$ & Minimum & Maximum \\
\hline Intragroup conflict & 217 & 19,02 & 6,17 & 9,00 & 45,00 \\
Intergroup conflict & 217 & 19,05 & 4,94 & 8,00 & 40,00 \\
Intrapersonal conflict & 217 & 13,29 & 4,32 & 6,00 & 30,00 \\
Total & $\mathbf{2 1 7}$ & $\mathbf{5 1 , 3 8}$ & $\mathbf{1 1 , 7 5}$ & $\mathbf{2 2 , 0 0}$ & $\mathbf{9 3 , 0 0}$ \\
\hline
\end{tabular}

The analysis revealed that according to the views of educational supervisors, the level of organizational conflict in head departments of educational supervisors was $\bar{X}=19,02$ for Intragroup conflict factor, $\bar{X}=19,05$ for Intergroup conflict factor, $\bar{X}=13,29$ for Intrapersonal conflict factor, and $\bar{X}=51,38$ for the overall scale. This suggests educational supervisors perceive that organizational conflicts in general and intragroup conflicts, intergroup conflicts, and intrapersonal conflicts in particular are experienced "sometimes" or moderately in head departments of educational supervisors. This moderate level of conflict can be considered positive, since excessive organizational conflicts in an organization can cause deviation from goals, poor productivity, hindrance, hostility, lack of objectivity, distortion, prejudices, and aggressiveness. On the other hand too little organizational conflict causes inertia, disharmony, reluctance, laziness, ignorance, indifference, extravagancy (Başaran, 2004, p. 329-330).

The findings about whether communication competence levels of heads of educational supervisors' significantly predict level of organizational conflict were presented in Table 4-8.

Tablo 4 
Simple Linear Regression Analysis Results about Whether Communication Competence Significantly Predict Organizational Conflict

\begin{tabular}{|c|c|c|c|c|c|c|c|}
\hline Variable & $B$ & $\begin{array}{c}\text { Standard } \\
\text { error }_{B}\end{array}$ & $\beta$ & $t$ & $p$ & $\begin{array}{c}\text { Zero } \\
\quad r \\
\end{array}$ & $\begin{array}{c}\text { Partial } \\
r \\
\end{array}$ \\
\hline Constant & 91,143 & 3,500 & & 26,044 &, $000^{*}$ & & \\
\hline $\begin{array}{l}\text { Communication } \\
\text { competence }\end{array}$ & -.324 & .028 & -.619 & -11.549 & $.000^{*}$ &,- 619 &,- 619 \\
\hline \multicolumn{8}{|c|}{$\mathrm{R}=.619 ; \quad \mathrm{R}^{2}=.383$} \\
\hline $\mathrm{F}=133.383 ; \mathrm{p}=.00$ & & & & & & & \\
\hline
\end{tabular}

The regression analysis revealed that communication competence is a significant predictor of organizational conflict $(\mathrm{F}=133.383 ; \mathrm{p}=.000)$. The correlation between communication competence and organizational conflict was found negative and moderate $(\mathrm{r}=-.619)$. Communication competence explains about $38 \%$ of the variance in organizational conflict $\left(\mathrm{R}^{2}=.383\right)$. Thus it can be said that as the heads of education supervisors' communication competence increases the organizational conflict decreases significantly.

\section{Table 5}

Multiple Linear Regression Analysis Results about Whether Empathy, Social Relaxation And Support Competences Significantly Predict Intergroup Conflict

\begin{tabular}{llllllll}
\hline Variable & $\mathrm{B}$ & $\begin{array}{l}\text { Standard } \\
\text { error } \mathrm{B}\end{array}$ & $\beta$ & $\mathrm{t}$ & $\mathrm{p}$ & Zero & Partial \\
& & & & $\mathrm{r}$ & $\mathrm{r}$ \\
\hline Constant & 32,911 & 1,701 & - & 19,346 &, $000^{*}$ & - & - \\
Empathy &,- 187 &, 061 &,- 509 & $-3,072$ &, $002^{*}$ &,- 206 &,- 171 \\
$\begin{array}{l}\text { Social } \\
\text { relaxation }\end{array}$ &,- 093 &, 126 &,- 109 &,- 743 &, 458 &,- 051 &,- 041 \\
Support &, 049 &, 085 &, 046 &, 574 &, 567 &, 039 &, 032 \\
\hline $\mathrm{R}=, 580 ; \quad \mathrm{R} 2=, 337$ & & & & & & \\
$\mathrm{~F}=36,029 ; \mathrm{p}=.000$ & & & & & & & \\
\hline
\end{tabular}

The regression analysis revealed that three types of communication competences together are significantly and moderately correlated with intergroup conflict $(\mathrm{R}=.580$; $\mathrm{p}=.000)$. They together explain about $34 \%$ of the variance in intergroup conflict $\left(\mathrm{R}^{2}\right.$ $=.337)$. Yet, $\mathrm{t}$ analysis about the significance of regression coefficients indicates that 
only empathy competence is a significant predictor of the intergroup conflict scores. The partial correlation between empathy competence and intergroup conflict was found negative and low $(\mathrm{r}=-.171)$.

Table 6

Multiple Linear Regression Analysis Results about Whether Empathy, Social Relaxation And Support Competences Significantly Predict Intragroup Conflict

\begin{tabular}{|c|c|c|c|c|c|c|c|}
\hline Variable & $B$ & $\begin{array}{c}\text { Standard } \\
\text { error }_{B}\end{array}$ & $\beta$ & $t$ & $p$ & $\begin{array}{c}\text { Zero } \\
r\end{array}$ & $\begin{array}{c}\text { Partial } \\
r\end{array}$ \\
\hline Constant & 36,160 & 2,294 & - & 15,765 &, $000^{*}$ & - & - \\
\hline Empathy & ,029 & ,082 & ,062 & ,349 & 728 & ,024 & ,021 \\
\hline $\begin{array}{l}\text { Social } \\
\text { relaxation }\end{array}$ & ,001 & ,169 & ,001 & ,003 & ,997 & ,000 & ,000 \\
\hline Support &,- 685 & ,114 &,- 520 & $-5,983$ &, $000^{*}$ &,- 379 &,- 360 \\
\hline $\begin{array}{l}\mathrm{R}=, 477 \\
\mathrm{~F}=20,915\end{array}$ & $\begin{array}{l}=, 228 \\
=.000\end{array}$ & & & & & & \\
\hline
\end{tabular}

The regression analysis revealed that three types of communication competences together are significantly and moderately correlated with intragroup conflict $(\mathrm{R}=.477$; $p=.000)$. They together explain about $23 \%$ of the variance in intergroup conflict $\left(R^{2}\right.$ $=.228)$. Yet, $\mathrm{t}$ analysis about the significance of regression coefficients indicates that only support competence is a significant predictor of the intragroup conflict scores. The partial correlation between support competence and intragroup conflict was found negative and moderate $(r=-.360)$.

Table 7

Multiple Linear Regression Analysis Results about Whether Empathy, Social Relaxation And Support Competences Significantly Predict Intrapersonal Conflict

\begin{tabular}{llllcccc}
\hline \multicolumn{1}{c}{ Variable } & $\boldsymbol{B}$ & $\begin{array}{c}\text { Standard } \\
\text { error }_{B}\end{array}$ & $\boldsymbol{\beta}$ & $\boldsymbol{t}$ & $\boldsymbol{p}$ & $\begin{array}{c}\text { Zero } \\
\boldsymbol{r}\end{array}$ & $\begin{array}{c}\text { Partial } \\
\boldsymbol{r}\end{array}$ \\
\hline Constant & 24,063 & 1,516 & - & 15,874 & $000^{*}$ & & \\
$\begin{array}{l}\text { Empathy } \\
\begin{array}{l}\text { Social } \\
\text { relaxation }\end{array}\end{array}$ &,- 114 &, 054 &,- 356 & $-2,106$ &, $036^{*}$ &,- 143 &,- 120 \\
\begin{tabular}{l} 
Support \\
\hline
\end{tabular} &, 097 &, 112 &,- 277 & $-1,849$ &, 066 &,- 126 &,- 105 \\
\hline
\end{tabular}

$\mathrm{R}=, 558 ; \quad \mathrm{R}^{2}=, 312$

$\mathrm{F}=32,136 ; \mathrm{p}=.000$

${ }^{*} \mathrm{p}<.05$ 
The regression analysis revealed that three types of communication competences together are significantly and moderately correlated with interpersonal conflict $(\mathrm{R}=$ $.558 ; \mathrm{p}=.000)$. They together explain about $31 \%$ of the variance in intergroup conflict $\left(\mathrm{R}^{2}=.312\right)$. Yet, $\mathrm{t}$ analysis about the significance of regression coefficients indicates that only empathy competence is a significant predictor of the intrapersonal conflict scores. The partial correlation between support competence and interpersonal conflict was found negative and low $(\mathrm{r}=-.120)$.

\section{Discussion and Conclusions}

One of the critical components of our education system is the head departments of educational supervisors which are responsible for providing feedback about the proper operation of the system and executing guidance, in-service training, supervision, inspection, assessment, research and investigation services. Head departments of educational supervisors work in every province under the affiliation of national education directorates. These units are composed of heads of educational supervisors, their deputies, educational supervisors and other officers. This study, which intended to investigate the association between the communication competences of heads of these departments and the level of organizational conflict therein, revealed that heads of educational supervisors "generally" display empathy, social relaxation and support competences, which are the components of communication competence. This finding supports the conclusions of Mulla (2008) that supervisors perceive themselves on a higher competency level and the conclusions of John (1997) that school principals perceive themselves confident in the performance of all communication skills. Also, fewer cultural differences among supervisory team may have contributed this result (Smeir, 2012). A study on special education directors produced similar findings. They perceived themselves as using more compromise, solution-orientation style and control styles (Biediger-Collins, 2000). One reason for this conclusion may be that supervisors' role was moving from authoritative to democratic (Fehr, 2001). On the other hand, the level of intragroup conflict, intergroup conflict, intrapersonal conflict, and total organizational conflict in head departments of educational supervisors were found "sometimes". As previous research findings indicate, the communication competence of the leader, and its affect on communication effectiveness as evidenced by member perception of leadermember agreement, appears to be a necessary precondition for a high quality leadermember exchange relationship. (Flauto, 1999; Kinnick, 2005; Myers and Kassing, 1998; Payne, 2005).

The analysis regarding the association between communication competence and organizational conflict revealed that communication competence is a significant predictor of organizational conflict, where former explains about $38 \%$ of the variance in the latter $\left(\mathrm{R}=.619, \mathrm{R}^{2}=.383, \mathrm{p}<.01\right)$. Based on the moderate negative correlation found between communication competence and organizational conflict $(r=-.619)$, it was concluded that as the communication competences of heads of educational supervisors gets better the organizational conflicts in head departments of 
supervisors also decreases. This finding is supported by previous researches on teachers (Şahin, 2010) athletes (Haselwood et al., 2005) and business students (Gross and Guerrero, 2000).

Among the three types of communication competences, only empathy competence was found to be a significant predictor of the intergroup conflict, with a negative low correlation (partial $\mathrm{r}=$-.171). Thus heads of educational supervisors are recommended to display empathic behaviors when it is needed to decrease the level of intergroup conflict in the head department.

Among the three types of communication competences, only support competence was found to be a significant predictor of the intergroup conflict, with a negative moderate correlation (partial $r=-.360$ ). Thus heads of educational supervisors are recommended to display empathic behaviors when it is needed to decrease the level of intergroup conflict in the head department. Thus it can be concluded that as the heads of educational supervisors display supportive behaviors in communication such as listening attentively, not interrupting, considering the feelings, caring what is said, the level of intragroup conflict will decrease.

Among the three types of communication competences, only empathy competence was found to be a significant predictor of the interpersonal conflict, with a negative low correlation (partial $\mathrm{r}=-.120$ ). Thus heads of educational supervisors are recommended to display empathic behaviors when it is needed to decrease the level of interpersonal conflicts in the head department.

In sum, the current study adds new understanding to the supervision process, particularly for the heads of supervisory team. It builds on the existing literature in the fields of communication, and conflict resolution. Additionally, the study only provided the perspective of supervisors. In order to arrive at a fuller understanding of communication competencies and conflict concept, additional research needs to be done from the perspective of head supervisors, supervisors and vice-supervisors specifically in job satisfaction, motivation, professional commitment and self-efficacy.

\section{References}

Açıkalın, A.(1998). Toplumsal, kuramsal ve teknik yönleriyle okul yöneticiliği. [School Leadership in social, theoretical and practical way] Ankara, Pegem-A Yayıncilık.

Atay, K.(2002). Okul müdürlerinin duygusal zeka düzeyleri ile çatışmaları çözümleme stratejileri arasındaki ilişki. [The relationship between emotional intelligence and conflict management strategies of school principals] Kuram ve Uygulamada Ĕ̈itim Yönetimi, 31, 344-355.

Aydın, M. (2000). Çă̆daş eğitim denetimi. [Contemporary Educational Supervision] Ankara, Hatiboğlu yayınevi.

Başar, H. (2000). Eğitim denetçisi. [Educational Supervisor] Ankara, Pegem-A yayıncilik. 
Başaran, İ. E.(2004). Yönetimde insan ilişkileri:Yönetsel Davranış.[Homan Relations in Management: Managerial Behaviour] 3.Baskı, Ankara, Nobel Yayın Dağıtım.

Biediger-Collins, A.R. (2000). Communication and conflict management styles as perceived by special education directors and their subordinates in region $\mathrm{XX}$ esc in Texas. Unpublished Dissertation, Texas A\&M University, USA.

Blackburn, H. C.(2002). Administrator gender differences in conflict management style and the relationship to school culture. Unpublished Dissertation, University of Missouri, Columbia. USA.

Blatt, S. J. \& Benz, C. (1993). The relationship of communication competency to perceived teacher effectiveness. Paper presented at the Joint Meeting of the southern states communication association and the central states communication association, Lexington, KY, April, 14-18, 1993.

Bursalığlu, Z.(1994). Okul yönetiminde yeni yapı ve davranış. [New Construct and Behaviour in School Administration] Ankara, Pegem: Personel geliştirme merkezi, Yayın No:9.

Çokluk, Ö., Şekercioğlu, G. \& Büyüköztürk, Ş. (2010). Sosyal bilimler için çok değişkenli istatistik:SPSS ve LISREL uygulamaları.[Multi-Factorial Statististics for Social Sciences: SPSS and LISREL Applications] Ankara, Pegem Akademi.

Craig, D.A.(2000). The relationship between communicative adaptability and perceived superintendent effectiveness. Unpublished Dissertation, Southern Illinois University, Carbondale.

Eren E. (2000). Örgütsel Davranış ve Yönetim Psikolojisi, [Organizational Behaviour and Management Psychology] Beta Basım Yayım, İstanbul.

Fehr, S.J.K. (2001). The role of the educational supervisor in United States public schools from 1970 to 2000 as reflected in the supervision literature. Unpublished Dissertation, Pennsylvania State University,USA.

Flauto, F. J. (1999). Walking the Talk: The Relationship Between Leadership and Communication Competence. Journal of Leadership \& Organizational Studies, 6(1-2), 86-97. doi:10.1177/107179199900600106

Fraenkel , J., Wallen, N., Hyun, H. (2012).How to design and evaluate research in education. 8th ed. Graw-Hill, New York, USA.

Gross, M.A., Guerrero, L.K. (2000). Managing conflict appropriately and effectively: An application of the competence model to Rahim's organizational conflict styles. International Journal of Conflict Management, 11(3), 200-226.

Gümüşeli, A. İ.(1994). İzmir ortaöğretim okulları yöneticilerinin öğretmenler ile aralarındaki çatışmaları yönetme biçimleri. [Conflict management styles between teachers and administrators of Izmir secondary schools] Unpublished Dissertation, Ankara Üniversitesi, Ankara.

Haselwood, D.M., Joyner, A., Burke, K.L., Geyerman, C.B., Munkasy, B.A., \& Zwald, A. (2005). Female atheletes' perceptions of head coaches' communication competence. Journal of Sport Behaviour, 28(3), 216-230. 
Hoy, W. K., Miskel, C. G. (2010). Eğitim yönetimi: Teori, araştırma ve uygulama. [Educational administration: theory, research, and practice], (Çeviri Editörü: Selahattin Turan), Ankara, Nobel Yayın Dağıtım.

Johns, C.(1997). Communication competencies necessary for effective educational leadership as perceived by public school principals. Unpublished Doctor of Education Dissertation, University of Houston.

Karip, E.(2003). Çatışma yönetimi. [Conflict Management]. Ankara, Pegem-A Yayıncilık.

Kinnick, K. N. (2005). Workplace Communication: What The Apprentice Teaches About Communication Skills. Business Communication Quarterly, 68(4), 429456. doi:10.1177/1080569905282099

Lee, F. M.(2003). Conflict management styles and emotional intelligence of faculty and staff at a selected college in southern Taiwan. Unpublished Dissertation, University of South Dakota, Taiwan.

Mulla, E. (2008). İlköğretimde görev yapan öğretmen ve ilköğretim müfettişleri açısından ilköğretim müfettişlerinin insan ilişkileri yeterlik düzeyleri.[Proficiency levels of primary school superviors' human relations in terms of primary school teachers and supervisors] Unpublished Master Thesis. Akdeniz Üniversitesi, Sosyal Bilimler Enstitüsü.

Myers, S. A., Kassing, J. W.(1998). The relationship between perceived supervisory communication behaviors and subordinate organizational identification. Communication Research Reports, 15(1), 71-81.

Özmen, F.(1997). Fırat ve İnönü Üniversitelerinde çatışma yönetimi yaklaşımları. [Conflict Management Strategies in Inonu and Firat Universities] Unpublished Dissertation, Frrat Üniversitesi, Elazığ.

Payne, H.J.(2005).Reconceptualizing social skills in organizations:Exploring the relationship between communication competence, job performance, and supervisory roles. Journal of Leadership and Organizational Studies, 11, 63-77.

Phillips, G. M. (1983). Acompetent view of "competence". Communication Education, $32,25-36$.

Polat, S. Ve Arslan, H.(2004). Yükseköğretim örgütünde görev yapan yöneticilerin çatışma yönetimi stratejilerini kullanma düzeyleri. [The level of using conflict management strategies of managers in higher education instutitions] Kuram ve Uygulamada Ĕ̆itim Yönetimi, 39, 430-457.

Rahim M.A. (2001). Managing Conflict in Organizations, Third Edition, Quorum Books Greenwood Publishing Group, Westport, CT.

Rahim, M. A.(1983). Rahim organizational conflict inventories: Professional manuel.(experimental ed.). Palo Alto, CA: Consulting Psychologists Press.

Rickheit, G., Strohner, H. \& Vorwerg, C. (2008). The concept of communicative competence. In G. Rickheit \& H. Strohner(Eds.), Handbook of communication competence (pp.16-62). Berlin \& New York. 
Robbins, S. P.(1994). Örgütsel davranışın temelleri. [The fundamentals of organization behaviours] (Trans: Sevgi Ayşe Öztürk), Etam Basım Yayım Ltd, Eskişehir.

Roberts, W. L.(1997). An investigation of relationship between principals' self efficacy beliefs and their methods of managing conflict with teachers. Unpublished Dissertation, Auburn University, Alabama.

Rubin, B. R. (1994). Development of a measure of interpersonal communication competence. Communication Research Reports, 11(1), 33-44.

Smeir, I. (2012). Cross-cultural conflict in the counseling supervision process: comparing supervisor's perceptions, conceptualizations, and recommendations when conflict arises with a supervisee. Unpublished Dissertation, Northern Illinois University Dekalb, Illinois, USA.

Şahin, A. (2010). İlköğretim okulu yöneticilerinin kişiler arası iletişim becerileri ve çatışma yönetimi stratejileri arasındaki ilişki. [The relationship between conflict management strategies and interpersonal communication levels of primary school administrators] Milli Ĕ̆itim, (188), 125.

Şimşek, M. Ş., Akgemci, T. Ve Çelik, A.(2001). Davranı̧ bilimlerine giriş ve örgütlerde davranış. [Introduction to behavioral sciences and organizational behavior] Ankara, Nobel yayınları.

Şimşek, Y. (2003). Okul müdürlerinin iletişim becerileri ile okul kültürü arasındaki ilişki: Eskişehir ili örneği. [The relationship between school culture and communication competency of school principals: Eskisehir Sample] Unpublished Dissertation, Anadolu Üniversitesi, Eskişehir.

Smith, B. A. S.(2004). Principal leadership communication strategies in high and low socioeconomic schools. Unpublished Dissertation, The University of Arizona, Arizona.

Sophie, J. H.(2004). A correlation of self-assessed leadership skills and interpersonal communication competencies of public school principals in five İllinois Counties. Unpublished doctoral dissertation, University of Northern İllinoisDekalb, İllinois.

Spitzberg, B. M. (1983). Communication competence as knowledge, skill, and impression. Communication Education, 32, 323-329.

Tabor, B.(2001). Conflict management and interpersonal communication style of the elementary principal. Unpublished Dissertation. University of Missouri, Columbia.

Topluer, A.(2008). İlköğretim okulu yöneticilerinin iletişim yeterlikleri ile örgütsel çatışma düzeyi arasındaki ilişki. [The relationship between organizational conflict and communication competency levels of primary school administrators] Unpublished Master Thesis, İnönü Üniversitesi, Malatya. 
Türnüklü, A. , Şahin, İ. Ve Öztürk, N.(2002). İlköğretim okullarında öğrenci, öğretmen, okul yöneticisi ve velilerin çatışma çözüm stratejileri. [Conflict management strategies of students, teachers, administrators and students' parents in primary schools] Kuram ve Uygulamada Eğitim Yönetimi, 32, 574-597.

Wiemann, J. M. (1977). Expication and test of a model of communicative competence. Human Communication Research, 3, 195-213.

Yıldırım, A.(2003). İlköğretim okulu yöneticilerinin empatik eğilimleri ve empatik becerileri ile çatışma yönetimi stratejileri arasındaki ilişki: Ankara ili örneği. [Emphatic levels of primary school administrators and the relationship between conflict management strategies and emphatic levels: Ankara Sample] Unpublished Dissertation, Ankara Üniversitesi, Ankara.

\section{İletişim Yeterliği ile Örgütsel Çatışma Arasındaki İlişki: Eğitim Denetmenleri Başkanlığı Üzerine Bir Araştırma}

Atıf: Üstüner, M., Kış, A. (2014). The Relationship between communication competence and organizational conflict: a study on head of educational supervisors. Eurasion Journal of Educational Research, 56, 1-24, DOI: http:/ / dx.doi.org/10.14689/ejer.2014.56.5

\section{Özet}

Problem Durumu: Denetimi, eğitimde gözetme yollarından biri olarak gören Bursalığlu (1994, s:129) kamu yararı adına davranışı kontrol yöntemi olarak tanımlamaktadır. Bunun yanı sıra denetimi uyumu sağlamanın bir gereği olarak düzenleyici mekanizmalardan en çok kullanılanı olarak da nitelendirmektedir. Denetim, örgütsel eylemlerin kabul edilen amaçlar doğrultusunda, saptanan ilke ve kurallara uygun olup olmadığının anlaşılması süreci olarak da tanımlanmaktadır. Denetimin temel amacı örgütün amaçlarının gerçekleştirilme derecesini saptamak, daha iyi sonuç alabilmek için gerekli önlemleri almak ve süreci geliştirmektir (Aydın, 2000, 11).

Eğitim denetçilerinin rolleri konusunda, rol oluşumundaki değişkenlerden kaynaklanan farklı rol sınıflandırmaları üzerinde duran Başar $(2000,39)$ denetçi rollerini görev, süreç ve davranış boyutlarını kapsayacak biçimde liderlik, yöneticilik, rehberlik ve yardım, eğiticilik, araştırma ve soruşturma rolleri olarak belirtmektedir. Diğer iş görenler gibi eğitim denetçilerinin de rollerinin gereklerini yerine getirebilmeleri için bazı yeterliklere sahip olmaları gerektiği üzerinde durulmaktadır.

İletişim yeterliği: Rickheit, Strohner ve Vorwerg'e $(2008,18)$ göre iletişim yeterliği kavramı 1960'l yıllarda Dell Hymes tarafından, iletişimde konuşma dili yeterliğinden ziyade gramer kuralları bilgisini vurgulamak için kullanılmıştır. 
Onlara göre, Wiemann (1977), Spitzberg ve Cupach (1984/1989) iletişim yeterliği kavramının kapsamının geliştirilmesinde önemli katkılarda bulunmuşlardır. Wiemann (1977) tarafından yapılan çalışmada iletişim yeterliği yaklaşımlarının tgrup, sosyal beceri, ve kendini ifade etme yaklaşımları olarak üç grupta ele alınabileceği vurgulanmaktadır. Wiemann (1977) iletişim yeterliğini “ iletişimde olan bir bireyin iletişimin amaçlarına ulaşma doğrultusunda durumun özelliklerini de dikkate alarak uygun davranışı seçme becerisi" olarak tanımladıktan sonra, iletişim yeterliğinin yakın ilişki (affiliation/support), sosyal rahatlık (social relaxation), empati (empathy), davranışsal esneklik (behavioral flexibility) ve etkileşim yönetimi (interaction management) olmak üzere beş temel alana ilişkin becerilerin bileşiminden meydana geldiğini belirtmiştir. Rubin ve Martin(1994), kişilerarası iletişim yeterliğini kendini açma(self-disclosure), empati (empathy), sosyal rahatlık(social relaxation), girişkenlik(assertiveness), etkileşim yönetimi(interaction management), diğeri-odaklılık (altercentrism), dışa vurumculuk (expressiveness), destekleyicilik (supportiveness), samimiyet(immediacy) ve çevresel kontrol(environmental control) boyutlarında ele almışlardır. Hoy ve Miskel (2010, 347) iletişim yeterliğini iletişim kuran kişinin sahip olduğu bir takım beceri ve kaynaklar olarak ele almaktadırlar. Bu kapsamda iletişim yeterliğine sahip bireylerin gönderme, dinleme ve geribildirim becerilerine sahip olması gerektiğini vurgulamaktadırlar.

Örgütsel Çatışma: Örgütsel çatışmanın tanımı farklı şekillerde yapılmıştır. Çatışmanın temelinde tarafların çatışmayı algılaması, muhalefet, zıtlık, engelleme ve çıkarlarıyla amaçları uyumsuz görünen iki ya da daha fazla tarafın bulunması gereklidir (Aydın, 2000, 292). Çatışma, taraflardan birinin diğerinin çabalarını etkisizleştirmek için yaptığı bir girişimdir (Robbins, 1994, 220). Örgütsel çatışma, bağdaştırılamaz ayrılıkları ya da uzlaşmaz özellikleri olan iş görenler ve kümeler arasındaki etkileşim durumudur. Bir birleriyle etkileşen kişilerin çatışma davranışı, bilişsel ve duygusal güçlerini etkileyen olaylara ve çelişkilere karşı yaptıkları bir tepkidir (Başaran, 2004, 323). Çatışmanın tanımı ne şekilde yapılırsa yapılsın anlaşmazlık, zıtlaşma, uyumsuzluk ve birbirine ters düşme çatışmanin temel unsurlarıdır. İnsanın etkileşim halinde olduğu toplumsal yaşamda çatışma kaçınılmaz bir olgudur (Bursalıŏlu, 2002, 155; Karip, 2003, 1; Şimşek, Akgemci, Çelik, 2001, 238). Çatışmanın olmadığı bir örgüt ölüdür. Yaşayan, etkililiği devam eden örgütlerde çatışmaların varlığı kaçınılmazdır ve doğaldır (Açıkalın, 1998, 107).

İletişimin hızla geliştiği ve değişimin örgütler için zorunlu olduğu günümüzde örgüt üyeleri arasındaki bireysel farklılıkların artması kaçınılmaz olmuştur. Bu durum sürekli etkileşim halinde bulunan örgüt üyeleri arasında çatışmaların artmasına neden olmaktadır (Karip, 2003, 1). İnsanlar arasında ortaya çıkan çatışmaların temelinde zayıf iletişim yatmaktadır. Bireyler arasında var olan iletişimin derecesi örgütün performansını ve bilgilerin aktarılmasını önemli ölçüde etkiler (Robbins, 1994, 141).

Araştırmanın Amacl: Bu araştırmanın amacı eğitim müfettişlerinin görüşlerine göre, eğitim müfettişleri başkanlarının iletişim yeterliği ile örgütsel çatışma arasındaki ilişki düzeyini belirlemektir.

Araştırmanın Yöntemi 
Çalışma Grubu: Araştırmanın çalışma grubunu 2009-2010 öğretim yılında, Adıyaman, Diyarbakır, Hatay, Kayseri, Malatya, Kahramanmaraş, Tokat ve Şanlıurfa Milli Eğitim Müdürlükleri, Eğitim Müfettişleri Başkanlıklarında görevli 217 eğitim müfettişi oluşturmaktadır. Bu illerde görev yapan toplam 446 eğitim müfettişinin tamamına ölçme araçları ulaştırılmasına rağmen 217 eğitim müfettişi araştırmaya katılmıştır.

Veri Toplama Araçları: Eğitim müfettişlerinin görüşlerine göre eğitim müfettişleri başkanlarının iletişim yeterliği ile örgütsel çatışma arasındaki ilişki düzeyini belirlemeyi amaçlayan bu araştırmada, Wiemann (1977) tarafından geliştirilen "iletişim yeterliği ölçeği-İYÖ” (Communicative Competence Scale) ve Rahim tarafından geliştirilen "örgütsel çatışma ölçeği-ÖÇÖ"(Rahim Organization Conflict Inventory; ROCI-I) ölçeklerinin Topluer(2008) tarafından yapılan Türkçe uyarlamaları kullanılmıştır.

Verilerin Çözümlenmesi: Araştırmada elde edilen verilerin analiz edilmesinde betimsel istatistikler ve doğrusal regresyon analizi kullanılmıştır. Ortalama puanların değerlendirilmesinde her bir ölçeğin alt ölçeklerinden alınan ortalama puanlar hesaplanmıştır.

Araştırmanın Sonuçları ve Önerileri: Eğitim müfettişleri başkanlıkları her ilde milli eğitim müdürlüğü bünyesinde, eğitim müfettişi başkanı, başkan yardımcıları, eğitim müfettişleri ve ilgili diğer memurlardan oluşan bir birim olarak belirlenen amaçlar doğrultusunda işleyişte bulunmaktadır. Bu birimlerin başkanlarının iletişim yeterlikleriyle birimlerde ki örgütsel çatışma arasındaki ilişkinin araştırıldığı bu araştırma sonucunda, eğitim müfettişi başkanlarının, iletişim yeterliğinin bileşenlerinden olan empati, sosyal rahatlık ve desteklemeye ilişkin davranışları "çoğu zaman" göstermekte oldukları gözlenmiştir. Bu bulgu Mulla (2008) tarafından da desteklenmektedir. Bununla birlikte eğitim müfettişleri başkanlıklarındaki grup içi çatışma, gruplar arası çatışma, kişisel çatışma ve toplam örgütsel çatışma miktarının da "bazen" düzeyinde olduğu gözlenmiştir. Önceki araştırma bulguları da bir liderin iletişim yeterliğinin kaliteli bir lider-üye ilişkisi için önşart olduğunu ortaya koymaktadır. (Flauto, 1999; Kinnick, 2005; Myers and Kassing, 1998; Payne, 2005).

İletişim yeterliğinin örgütsel çatışmayı yordama düzeyine ilişkin olarak yapılan analiz sonucunda, iletişim yeterliği ile örgütsel çatışma arasında kısmi korelasyonun negatif yönlü ve orta düzeyde $(\mathrm{r}=-.619)$ olduğu görülmüştür. İletişim yeterliği değişkeni, örgütsel çatışma puanı ile orta düzeyde ve anlamlı bir ilişki göstermektedir $\left(\mathrm{R}=.619, \quad \mathrm{R}^{2}=.383, \mathrm{p}<.01\right)$. İletişim yeterliği değişkeni örgütsel çatışmadaki toplam varyansın yaklaşık \% 39'nu $\left(\mathrm{R}^{2}=.383\right)$ açılklamaktadır. $\mathrm{Bu}$ bulguya göre, örgütsel çatışma üzerinde iletişim yeterliği manidar ve ters yönlü bir etki değişkenidir. Bu bulgu öğretmenler (Şahin, 2010) sporcular (Haselwood et al., 2005) ve işletme öğrencileri (Gross and Guerrero, 2000) üzerine yapilan araştırma bulgularıly da desteklenmektedir.

İletişim yeterliği bileşenlerinden olan empati ile gruplar arası çatışma arasında negatif yönlü ve düşük düzeyde $(\mathrm{r}=-.206)$, sosyal rahatlık ile gruplar arası çatışma arasında negatif yönlü ve düşük düzeyde(r=-.051), destekleme ile gruplar arası çatışma arasında pozitif yönlü ve düşük düzeyde $(r=.039)$ bir ilişkinin olduğu gözlenmiştir. Empati, sosyal rahatlık ve destekleme değişkenleri, gruplar arası 
çatışma puanı ile orta düzeyde ve anlamlı bir ilişki göstermekte $(\mathrm{R}=.580)$ ve gruplar arası çatışmanın yaklaşık \%34'nü açıklamaktadır. Empatinin gruplar arası çatışma üzerinde önemli (manidar) bir yordayıcı ve ters yönlü bir etki değişkeni olduğu gözlenmiştir. Eğitim müfettişleri başkanlarının insanları konuşmaya teşvik etmesi, onları girişimlerinde desteklemesi, onları anlamaları ve bunu hissettirmeleri, samimi, sakin ve dikkatli bir dinleyici olmaları, iyi geçinmesi ve uyumlu olması gibi davranışlarının gruplar arası çatışma miktarı ile negatif yönlü bir ilişki gösterdiği görülmektedir. Gruplar arası çatışma miktarının azaltılması gerektiği bir durumda eğitim müfettişleri başkanlarının empatik davranışlar sergilemeye özen göstermeleri önerilebilir.

İletişim yeterliği bileşenlerinden olan empati ile grup içi çatışma arasında pozitif yönlü ve düşük ( $r=-.024)$, sosyal rahatlık ile grup içi çatışma arasında sıfır düzeyinde $(\mathrm{r}=.000)$, destekleme ile grup içi çatışma arasında negatif yönlü ve orta düzeyde(r=.379) bir ilişkinin olduğu gözlenmiştir. Empati, sosyal rahatlık ve destekleme değişkenleri, grup içi çatışma puanı ile orta düzeyde ve anlamlı bir ilişki göstermekte $(\mathrm{R}=.477)$ ve gruplar arası çatışmanın yaklaşı \%23'nü açıklamaktadır. Desteklemenin gruplar içi çatışma üzerinde önemli (manidar) bir yordayıcı olduğu görülmüştür. Buna göre gruplar içi çatışma üzerinde destekleme yeterliğinin manidar ve ters yönlü bir etki değişkeni olduğu görülmüştür. Eğitim müfettişleri başkanlarının iletişimde destekleyici davranışlar sergilemeleri, örneğin, iyi bir dinleyici olması, söz kesmemesi, duyguları dikkate alması, söylenenlere önem vermesi ve ilgilenmesi gibi davranışlarla grup içi çatışma miktarı negatif yönlü bir ilişki göstermektedir. Eğitim müfettişleri başkanlarının grup içi çatışma miktarını azaltmada bu tür davranışlara özen göstermeleri önerilebilir.

Empati ile kişisel çatışma arasında negatif yönlü ve düşük düzeyde bir ilişkinin(r= .143), sosyal rahatlık ile kişisel çatışma arasında negatif yönlü ve düşük düzeyde bir ilişkinin( $(\mathrm{r}=$-.126), destekleme ile kişisel çatışma arasında pozitif yönlü ve düşük düzeyde bir ilişkinin ( $r=.082)$ olduğu görülmüştür. Empati, sosyal rahatlık ve destekleme değişkenleri, kişisel çatışma puanı ile orta düzeyde $(R=.558)$ ve anlamlı bir ilişki göstermektedir. Empatinin kişisel çatışma üzerinde önemli (manidar) bir yordayıcı olduğu görülmüştür. Buna göre kişisel çatışma üzerinde empati yeterliğinin manidar ve ters yönlü bir etki değişkeni olduğu görülmektedir. Kişisel çatışma miktarının azaltılması gerektiği bir durumda eğitim müfettişleri başkanlarının empatik davranışlar sergilemeye özen göstermeleri önerilebilir.

Anahtar Kelimeler: Eğitim denetmeni, İletişim yeterliği, Örgütsel çatışma. 